\title{
PENGARUH INTRODUKSI ISOLAT RIZOBAKTERI INDIGEN TERHADAP PERTUMBUHAN DAN HASIL TANAMAN KENTANG (Solanum tuberosum L.) DAN DINAMIKA POPULASI GULMA DI ALAHAN PANJANG, SUMATERA BARAT
}

\author{
(Indigenous Rhizobacteria Affected the Growth and Yield of Potato (Solanum tuberosum L.) and Weed \\ Population Dynamics at Alahan Panjang, West Sumatera) \\ FRISKIA HANATUL QOLBY ${ }^{1}$, IRAWATI CHANIAGO ${ }^{2 *}$, INDRA DWIPA ${ }^{2}$, ZURAI RESTI $^{3}$ \\ ${ }^{1)}$ Pascasarjana Program Studi Agronomi, Fakultas Pertanian, Universitas Andalas, Padang \\ ${ }^{2)}$ Program Studi Agroteknologi, Fakultas Pertanian, Universitas Andalas, Padang \\ ${ }^{3)}$ Program Studi Proteksi Tanaman, Fakultas Pertanian, Universitas Andalas, Padang \\ *Email: irawati@agr.unand.ac.id
}

\begin{abstract}
Potato (Solanum tuberosum L.) is of important major crops for its carbohydrate and plays important roles to support food sovereignty along with rice, wheat, corn, and sorghum. Potato growth and yield at West Sumatra has not reached its maximum potential due to some factors including cultivation. One major important constraint in potato growing in West Sumatra is the fact that farmers use the $8^{\text {th }}$ to $12^{\text {th }}$ generation of potato seedlings which have a very low agronomic potential. Yet, weeds have caused another problem in the field and reduce potato yield. An experiment has been conducted at the Laboratory of Microbiology, Faculty of Agriculture, Universitas Andalas and Nagari Alahan Panjang, Subdistrict Lembah Gumanti, Solok Regency from November 2018 to March 2019. The experiment was aimed at determining the best indigenous rhizobactria isolates to increase the growth and yield of potato plants as well as weed population dynamics associated with potato plants. Six isolates of indigenous rhizobacteria and a control treatment group were tested in a completely randomised design with three replicates. The isolates were L1 S3.1, L1 S3.2, L1 S4.4, L2 S1.2, L2 S2.3, L2 S3. 2. Data were analyzed with analysis of variance and mean separation with Duncan's New Multiple Range Test (DNMRT) at 5\%. Results showed that isolate L1 S4.4 was best in increasing the number of branches, number of tubers, and weight of potato yield. The isolates tested affected weed populations dynamics, prior to treatments there were 8 species of weeds found at the field i.e Bidens pilosa L., Leptochloa chinensis, Eleusine indica L., Agerathum conyzoides, Richardia sp., Galinsoga parviflora, and Sonchus arvensis. During potato growing at the field, weed species of Eleusine indica L. and Gynura divaricata dissappeared from the soil. In contrast, Amaranthus spinosus emerged demonstrating that weed population dynamic has occurred.
\end{abstract}

Keywords : rhizobacteria, potato, weed.

\section{PENDAHULUAN}

Permintaan kentang pada pasar domestic terus meningkat mengiringi peningkatan populasi, kesadaran akan makna sehat, pendapatan per kapita, pasar luar negeri, dan peningkatan permintaan industri pengolahan kentang. Badan Pusat Statistika (2017) melaporkan produktivitas dan produksi kentang mengalami peningkatan. Sebagai contoh, hasil kentang dilaporkan sebanyak 17,67 ton/ha, 18,20 ton/ha, dan 18,25 ton/ha masing-masing pada tahun 2014, 2015, dan 2016. Akan tetapi, peningkatan produksi kentang belum cukup untuk memenuhi permintaan pasar dalam negeri. Hal ini terreflesikan pada impor kentang Indonesia yang mencapai 12,77 ton pada tahun 2016.
Sumatera Barat termasuk salah satu provinsi sentra produksi kentang di Indonesia. Beberapa daerah sentra produksi kentang di Sumatera Barat antara lain Kabupaten Solok, Kabupaten Tanah Datar, Kabupaten Solok Selatan, dan Kabupaten Agam. Varietas kentang yang digunakan umumnya adalah varietas Cingkariang (batang hitam), varietas Cipanas dan varietas Granola dengan ratarata produktivitas lima tahun terakhir berkisar antara 15,36-17,59 ton/Ha. Produktivitas ini masih rendah dibanding potensinya sebesar 26 ton/ha (Balai Pengkajian Teknologi Pertanian Sukarami, 2010).

Salah satu masalah utama dalam budidaya tanaman kentang adalah pengendalian organisme pengganggu tanaman, termasuk gulma, yang belum 
dilaksanakan secara ramah lingkungan. Kehilangan hasil tanaman kentang oleh keberadaan gulma telah banyak dilaporkan. Gulma yang dikendalikan pada 3 (tiga) minggu setelah muncul lapang dapat menigkatkan hasil kentang sebanyak 30-35\% (Mehring et al., 2016). Sebaliknya, gulma yang tidak dikendalikan dapat menyebabkan kehilangan hasil sampai 45-65\% (Nelson, dan Thoreson, 1981; Nelson dan Giles, 1989). Petani sering mengaplikasikan pestisida, fungisida, ataupun herbisida secara intensifuntuk mengendalikan organisme pengganggu tanaman. Kebanyakan mengaplikasikan produk agrokimia tersebut hanya berdasarkan pengalaman dan terkadang mengabaikan prosedur dan penanganan pestisida secara tepat. Aplikasi secara intensif produk agrokimia tersebut dapat menimbulkan resistensi (Bertholdsson, 2012) dan dapat menimbulkan dampak negative terhadap lingkungan. Residu herbisida di dalam tanah juga dapat menyebabkan ketidakseimbangan ekosistem dan dapat mempengaruhi kesehatan organisme lainnya termasuk manusia sebagai konsumen produk pertanian.

Berbagai upaya dapat dilakukan untuk meningkatkan produktivitas tanaman kentang antara lain dengan cara peningkatan kualitas tanaman budidaya melalui pemanfaatan mikroorganisme (bakteri, alga, jamur, dsb) yang mampu meningkatkan serapan hara dan efisiensi air. Selain itu juga dapat dilakukan pembersihan lingkungan tempat tumbuh tanaman dari semua vegetasi gulma, karena gulma yang berada pada areal pertanaman akan dapat mempengaruhi pertumbuhan dan hasil tanaman karena kemampuannya untuk bersaing dengan tanaman budidaya dalam memanfaatkan sumberdaya seperti air, sinar matahari, dan hara mineral (Reddy et al., 2013; Armada et al., 2016).

Salah satu upaya meningkatkan kkulaitas pertumbuhan tanaman budidaya adalah dengan memanfaatkan rizobakteria indigenus yang bersifat sebagai plant growth promotong rhizobacteria (PGPR). Jenis bakteri ini memberi manfaat dan mampu mengkoloni daerah perakaran (rizosfir-sekitar 1-2 mm di sekitar perakaran). Koloni tersebut membantu pertumbuhan tanaman melalui kemampuan bakteri dalam membantu penyerapan akar, produksi hormon pertumbuhan seperti auksin, giberelin, dan sitokinin. Beberapa jenis PGPR juga terbukti mampu membantu melarutkan fosfat dan fiksasi nitrogen (Beneduzi et al., 2012; Dawwam et al., 2013). Jenis PGPR lainnya dapat berperan sebagai biostimulant, bioprotectant, biofertilizer, dan bioherbicida (Banach et al., 2019) yang terbukti mampu meningkatkan kebugaran tanaman dan memberi perlindungan terhadap cekaman lingkungan melalui peningkatan ketersediaan hara, penyediaan hormon tumbuh, dan metabolit sekunder lainnya (Hardoim et al., 2015; Santoyo et al., 2016).

Pengendalian organisme pengganggu tanaman yang dilakukan secara ramah lingkungan telah menjadi issu global dalam beberapa decade terakhir. Sebaliknya, pemanfaatan produk alami dalam meningkatkan pertumbuhan dan hasil tanaman telah menjadi perhatian para peneliti dari berbagai belahan dunia. Aplikasi rizobakteri tidak secara langsung dapat mengendalikan gulma. Akan tetapii, asosiasi rizobakteri indigenus dan perakaran tanaman dapat meningkatkan vigor dan kebugaran dapat meningkatkan pertumbuhan tanaman kentang (Vejan et al., 2016; Pérez-Fernández, M. and Alexander, 2017). Peningkatan kebugaran dan pertumbuhan tanaman tentunya akan dapat meningkatkan kemampuannya dalam berkompetisi terhadap gulma. Carvalho et al., (2007) melaporkan bahwa rizobakteri juga dapat menghasilkan senyawa anti metabolit yang mampu menghambat pertumbuhan gulma Brachiaria decumbens sampai $52 \%$ dan $42 \%$ dari gulma uji menunjukkan pertumbuhan abnormal.

Penelitian ini bertujuan untuk mempelajari peran dan pengaruh isolat rizobakteri indigenus dalam meningkatkan pertumbuhan dan hasil tanaman kentang var. Granola di Alahan Panjang, Sumatera Barat. Selain itu, dinamika populasi gulma pertanaman kentang dengan aplikasi isolat rizobakteri indigenus juga menjadi fokus dalam penelitian ini.

\section{BAHAN DAN METODE}

Penelitian ini dilaksanakan pada bulan November 2018 - Maret 2019 di Jorong Galagah, Kenagarian Alahan Panjang, Kecamatan Lembah Gumanti, Kabupaten Solok, Sumatera Barat, dengan ketinggian tempat 1.400-1.600 mdpl. Perbanyakan dan karakterisasi isolat rizobakteria indigenus dilakukan di Laboratorium Mikrobiologi Fakultas Pertanian Universitas Andalas, Padang.

\section{Isolasi rizobakteri}

Sebanyak sekitar $200 \mathrm{~g}$ sampel tanah diambil masing-masing secara komposit pada 25 titik lokasi pertanaman kentang di Jorong Galagah, Alahan Panjang, Sumatera Barat. Tanah kemudian dimasukkan kedalam kantong plastik bening yang telah diberi label 
iodan segera dimasukkan ke dalam ice box dengan suhu $4^{\circ} \mathrm{C}$ sebelum disimpan di laboratorium.

Sepuluh g sampel tanah ditimbang dan ditambahkan $10 \mathrm{~mL}$ akuades murni dan dihomogenkan pada Vortex selama 3-5 menit. Suspensi larutan yang terbentuk kemudian diencerkan berulang sampai didapatkan suspensi dengan konsentrasi $10^{-6}$.

Sebanyak $100 \mu \mathrm{L}$ suspensi tersebut dimasukkan kedalam tabung reaksi yang berisi larutan media NA dan kemudian dihomogenkan pada Vortex sebelum dituangkan ke dalam cawan Petri dan diinkubasi pada suhu kamar selama 48 jam. Kemudian, proses pemurnian isolat dilakukan beberapa kali dengan cara menggoreskan isolate dengan jarum Ose pada media Nutrient Agar (NA). Karakterisasi morfologis terhadap rizobakteri yang tumbuh pada kultur murni pada proses isolasi tersebut telah dilaporkan oleh Chaniago et al. (2019). Beberapa isolate yang diperoleh, kemudian diaplikasikan pada umbi kentang var. Granola dalam penelitian ini.

\section{Introduksi rizobakteri indigen kepada umbi kentang var. Granola}

Sebanyak enam isolat digunakan pada percobaan ini yaitu L1 S3.1; L1 S3.2; L1 S4.4; L2 S1.2; L2 S2.3; dan L2 S3.2. Isolat tersebut diperbanyak dalam media cair Nutrient Broth (NB). Koloni tunggal murni rizobakteri dicampurkan kedalam $25 \mathrm{~mL}$ media NB dan diinkubasi selama 24 jam pada suhu kamar yang diletakkan pada rotary shaker dengan kecepatan $150 \mathrm{rpm}$. Kemudian, hasil kultur tersebut dimasukkan kedalam $250 \mathrm{~mL}$ larutan air kelapa steril dan kembali diletakkan pada rotary shaker dengan kecepatan $150 \mathrm{rpm}$ selama 48 jam pada suhu kamar. Hasil prekultur tersebut kemudian diencerkan dengan menambahkan kedalam $5 \mathrm{~L}$ air kelapa murni dan diinkubasi selama tujuh (7) hari di dalam wadah yang diberi aerasi untuk menjamin tercukupkannya suplai oksigen. Kerapatan populasi rizobakteri diuji dan dibandingkan dengan larutan McFarland skala 8 dengan populasi bakteri sekitar $10^{8} \mathrm{CFU} / \mathrm{mL}$. Larutan kultur akhir ini siap untuk diintroduksikan ke umbi kentang sebelum ditanam di lapang.

\section{Penanaman kentang di lahan percobaan}

Enam isolat rizobakteri L1 S3.1; L1 S3.2; L1 S4.4; L2 S1.2; L2 S2.3; dan L2 S3.2 dan tanpa isolat sebagai perlakuan. Sebelum diintroduksikan kepada umbi kentang var Granola generasi ke-dua (G2), semua isolat telah melewati uji Hypersensitive Reaction
(HR) pada daun tanaman Mirabilis jalapa, untuk memastikan bahwa semua isolat uji tidak bersifat pathogen terhadap tanaman.

Percobaan dilakukan menurut rancangan acak lengkap dengan tiga ulangan. Umbi kentang dengan berat sekitar $30-45 \mathrm{~g}$ dan memiliki 3-4 mata tunas direndam dalam larutan rizobakteri selama 15 menit sebelum ditanam. Satu umbi kentang ditanam pada setiap lubang tanam dengan kedalaman $5 \mathrm{~cm}$ dari permukaan tanah. Jarak tanam yang digunakan adalah $80 \mathrm{~cm} \times 30 \mathrm{~cm}$. Umbi kentang kemudian ditutupi dengan tanah untuk menghindari paparan langsung sinar matahari. Sisa larutan rizobakteri disiramkan ke tanah di sekitar umbi kentang sesuai perlakuan. Satuan percobaan berukuran $390 \mathrm{~cm} \times 320 \mathrm{~cm}$ dan terdapat 52 tanaman kentang pada setiap satuan percobaan. Pada saat pengolahan lahan dilakukan penambahan kapur dolomit $1400 \mathrm{~kg} / \mathrm{ha}$ untuk meningkatkan pH tanah. Bahan organik berupa pupuk kandang ayam juga diaplikasikan dengan dosis 10 ton/ha. Pupuk urea, SP36, dan $\mathrm{KCl}$ diberikan setengah dosis rekomendasi.

Sebelum pengolahan lahan dilakukan analisis gulma yang tumbuh pada lokasi percobaan. Pengambilan sampel gulma dilakukan pada lima titik secara diagonal dengan metode kuadrat dengan ukuran petak sampel masing-masingnya $1 \mathrm{~m} \times 1 \mathrm{~m}$. Delapan minggu setelah tanam (8 MST) dilakukan kembali identifikasi gulma yang tumbuh pada setiap petak percobaan. Gulma diidentifikasi, ditimbang bobot segar dan bobot keringnya (setelah dikeringovenkan pada suhu $80^{\circ} \mathrm{C}$ selama 48 jam). Data pertumbuhan dan hasil tanaman kentang pada akhir penelitian dianalisis statistika menurut sidik ragam dan pembandingan nilai tengah menurut DNMRT pada taraf $5 \%$. Data identifikasi gulma diolah secara deskriptif dan disajikan dalam bentuk niai summed dominance ratio (SDR).

\section{HASIL DAN PEMBAHASAN}

Hasil penelitian menunjukkan bahwa introduksi isolat rizobakteri indigen dapat meningkatkan pertumbuhan dan hasil tanaman kentang serta mempengaruhi dinamika populasi gulma. Perubahan spesies gulma yang diamati pada penelitian ini adalah suatu hal yang menarik untuk dikaji. Beberapa jenis gulma ditemukan sebelum olah tanah dan beberapa jenis gulma lainnya muncul pada periode pertumbuhan tanaman kentang. Data tentang dinamika populasi gulma tersebut disajikan pada Gambar 1 

Rata-rata nilai SDR sebelum
perlakuan

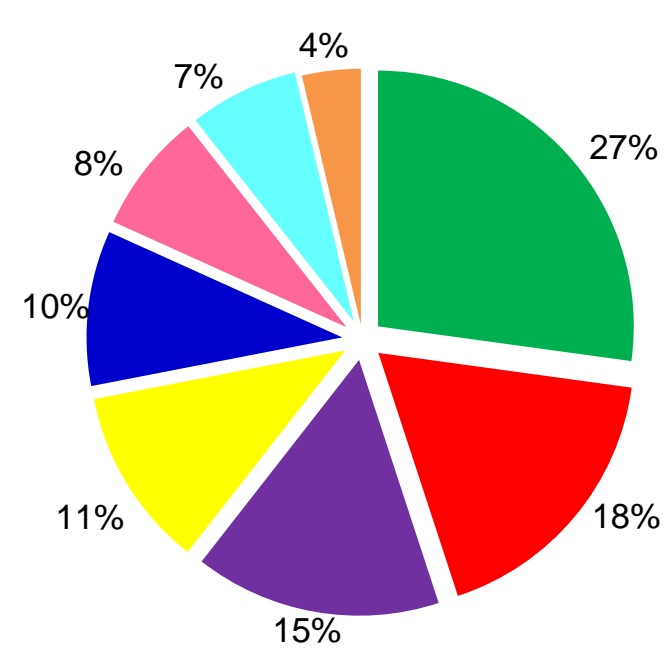

- Bidens pilosa $L$.

- Leptochloa chinensis

- Agerathum conyzoides

Eleusin indica $L$.

- Gynura divaricata

- Richardia sp

Galinsoga parviflora

- Sonchus arvensis
Rata-rata nilai SDR setelah perlakuan

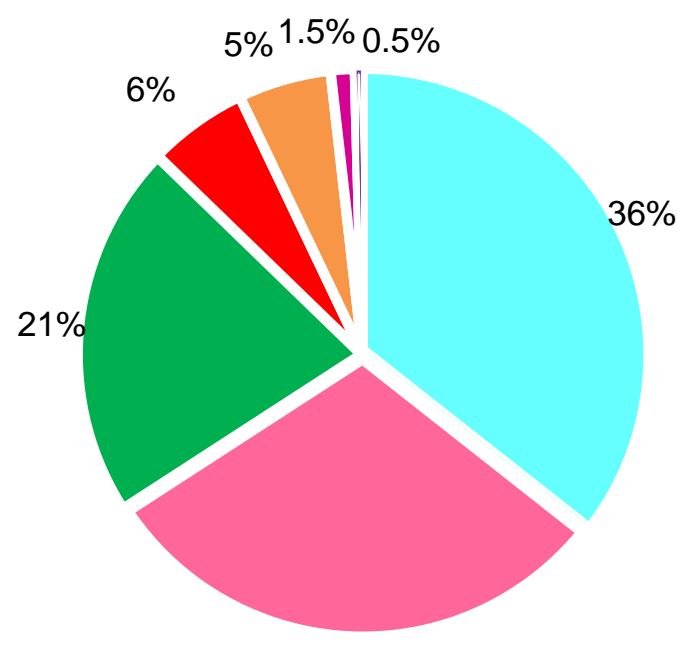

$30 \%$

Gambar 1. Nilai summed dominance ratio (SDR) gulma yang ditemukan pada lahan percobaan.

(a) gulma yang teridentifikasi sebelum olah tanah (b) gulma yang teridentifikasi pada pertanaman kentang setelah $8 \mathrm{MST}$.

\begin{abstract}
Ada beberapa faktor yang mempengaruhi asosiasi gulma dengan tanaman kentang antara lain cadangan biji gulma yang tersimpan di dalam tanah (seed bank). Pengolahan lahan dapat memindahkan bagian tanah ke permukaan dan memberi kesempatan kepada bagian tanah tersebut untuk mendapat aerasi dan kelembaban yang cukup. Pengolahan lahan juga dapat memfasilitasi cadangan biji gulma di dalam tanah untuk dapat berkecambah (Chauhan and Preston, 2006) dan berhubungan erat dengan distribusi biji gulma di permukaan tanah. Delapan spesies gulma ditemukan sebelum olah tanah. Akan tetapi gulma Eleusine indica (golongan rerumputan) dan Gynura divaricata (golongan gulma berdaun lebar) tidak ditemukan pada 8 MST kentang. Gulma Amaranthus spinosus (golongan gulma berdaun lebar) tumbuh bersama tanaman kentang dan menggantikan gulma Eleusine
\end{abstract}

indica. Penurunan sebanyak 90\% SDR gulma Ageratum conyzoides diduga dapat disebabkan karena pengaruh negatif rizobakteri yang disebut dengan fenomena allelopati (Barto et al., 2011) yang mempengaruhi pertumbuhan gulma tertentu. Sebaliknya, nilai SDR gulma Galinsonga parviflora meningkat dari $6 \%$ menjadi $36 \%$.

Sebelum perlakuan ditemukan 8 spesies gulma Bidens pilosa L. , Leptochloa chinensis, Eleusin indica L., Agerathum conyzoides, Gynura divaricata, Richardia sp, Galinsoga parviflora, dan Sonchus arvensis. Setelah perlakuan ditemukan 7 spesies gulma dengan gulma dominan yaitu Galinsoga parviflora, Bidens pilosa L., Richardia sp, Sonchus arvensis, Leptochloa chinensis, Ageratum conyzoides, dan Amaranthus spinosus.

Gulma berdaun lebar merupakan gulma yang dominan pada lahan percobaan sebelum perlakuan, spesies gulma berdaun 
lebar dengan dominasi tertinggi yaitu Bidens pilosa L. dan disusul oleh Agerathum conyzoides. Kedua spesies gulma ini merupakan famili Asteraceae. Famili asteraceae mempunyai daya adaptasi dan daya saing yang tinggi utnuk tumbuh di lingkungan, Heyne (2011) menyatakan bahwa adaptasi dan daya kompetisi suku Asteraceae lebih tinggi bila dibandingkan dengan spesies yang lain. Selain itu, spesies tersebut tidak membutuhkan syarat hidup yang begitu tinggi, cepat tumbuh lebat dan mampu memperbanyak diri secara alami dengan mudah. Gulma Ageratum conyzoides yang termasuk kedalam famili ini juga merupakan salah satu spesies yang mampu hidup pada daerah yang kering maupun lembab, tumbuh di tepi jalan, tanggul, dan sekitar saluran air dan hidup pada ketinggian 1-2.100 mdpl (Dalimartha, 2006).

Gulma yang terdapat sebelum perlakuan namun tidak ditemukan setelah perlakuan ada 2 spesies yaitu Eleusin indica $\mathrm{L}$. dan Gynura divaricata sedangkan gulma yang tidak ditemukan sebelum perlakuan namun ditemukan setelah perlakuan ada 1 spesies yaitu Amaranthus spinosus. Eleusin indica L. dan Gynura divaricata yang tidak ditemukan setelah perlakuan diduga karena seedbank dari gulma tersebut yang berada didalam tanah masih dalam kondisi dorman, hal ini sesuai dengan pernyataan Paiman et al. (2012) yang menyatakan bahwa perbedaan jumlah dan jenis spesies gulma yang tumbuh di tempat pengambilan tanah dan polibag disebabkan adanya sifat dormansi dan perpindahan biji gulma. Sifat dormansi memungkinkan suatu spesies gulma dapat bertahan dalam waktu yang lama di dalam tanah tergantung spesiesnya.

Terjadinya penurunan nilai SDR pada Agerathum conyzoides sebelum perlakuan dari $15 \%$ menjadi $3,09 \%$ pada perlakuan isolat $\mathrm{L} 1$ S3.1 diduga sebagai pengaruh dari rizobakteria indigenus yang memiliki kemampuan sebagai deleterious rhizobacteria melalui mekanisme allelopati. Spesies gulma Amaranthus spinosus yang ditemukan setelah perlakuan diduga muncul dari seedbank dari gulma tersebut yang diakibatkan oleh olah tanah dan dormansi biji yang telah selesai. Hal tersebut sesuai dengan pernyataan Suveltri (2014) yang menyatakan bahwa olah tanah sempurna (OTS) dapat memberikan peluang bagi biji gulma yang dorman untuk berkecambah akibat pembalikan tanah kemudian tumbuh dan berkembang mengikuti pertumbuhan tanaman sehingga dapat mempengaruhi produktivitas tanaman.

Perbedaan respon pertumbuhan dan hasil tanaman kentang ditemukan pada isolat rizobakteri indigenus yang berbeda. Semua isolat uji mampu meningkatkan jumlah cabang dan jumlah umbi per tanaman dibandingkan perlakuan tanpa isolat (Tabel 1).

Tabel 1. Respon pertumbuhan dan hasil tanaman kentang var. Granola pada 12 MST terhadap isolat rizobakteri indigen

\begin{tabular}{ccccc}
\hline Perlakuan & Jumlah cabang & Jumlah umbi & $\begin{array}{c}\text { Bobot umbi per } \\
\text { tanaman }\end{array}$ & $\begin{array}{c}\text { Bobot umbi per } \\
\text { hektar }\end{array}$ \\
\hline $\begin{array}{c}\text { Tanpa rizobakteri } \\
\text { indigen }\end{array}$ & $2.80 \mathrm{a}$ & $3.67 \mathrm{a}$ & $116.67 \mathrm{a}$ & $4.70 \mathrm{a}$ \\
L2 S1.2 & $3.13 \mathrm{~b}$ & $5.07 \mathrm{~b}$ & $248.67 \mathrm{bc}$ & $9.17 \mathrm{~b}$ \\
L1 S3.2 & $3.20 \mathrm{~b}$ & $5.67 \mathrm{~cd}$ & $217.33 \mathrm{~b}$ & $9.09 \mathrm{~b}$ \\
L2 S2.3 & $4.07 \mathrm{c}$ & $5.13 \mathrm{c}$ & $244.00 \mathrm{c}$ & $11.30 \mathrm{bc}$ \\
L2 S3.2 & $4.13 \mathrm{~cd}$ & $6.73 \mathrm{~d}$ & $285.70 \mathrm{~cd}$ & $11.70 \mathrm{bc}$ \\
L1 S3.1 & $4.20 \mathrm{~cd}$ & $6.53 \mathrm{~d}$ & $315.67 \mathrm{~cd}$ & $13.37 \mathrm{c}$ \\
L1 S4.4 & $4.30 \mathrm{~d}$ & $7.33 \mathrm{~d}$ & $345.40 \mathrm{~d}$ & $14.05 \mathrm{c}$ \\
\hline
\end{tabular}

Respon positif yang dilihat pada pertumbuhan dan hasil tanaman kentang menunjukkan bahwa rizobakteri indigenus yang diintroduksi kepada umbi kentang ikut berperan dalam memacu pertumbuhan tanaman. Semua isolat rizobakteri secara signifikan meningkatkan pertumbuhan dan hasil. Perbedaan karakter fisiologis rizobakteri telah banyak dilaporkan, termasuk kemampuan dalam menghasilkan fitohormon auksin (Patten and Glick, 2002), menurunkan kadar hormone etilen pada tumbuhan (Glick et al., 2007), kemampuan melarutkan unsur $\mathrm{Fe}$ oleh siderophore (Andrews et al., 2003; Krewulak and Vogel, 2008; Osório et al.,
2008), dan antibiotic (Beneduzi et al., 2012).

Salah satu kontribusi penting rizobakteri dalam mendorong pertumbuhan tanaman adalah kemampuan dalam menghasilkan auksin. Auksin dapat meningkatkan pertumbuhan tanaman melalui perkembangan sel, induksi terbentuknya system perakaran, induksi pembungaan, dan meningkatkan aktivitas enzim tertentu (Egamberdiyeva, 2007). Meningkatnya jumlah cabang tanaman biasanya akan diikuti dengan peningkatan tajuk dan daun (Compant, 2005) sebagai jaringan yang berfungsi fotosintetik dan transpirasi. Tumbuhan akan dapat melakukan proses fotosintesis secara efektif jika didukung 
oleh factor lingkungan yang optimal. Peningkatan jumlah cabang secara signifikan tidak selalu berhubungan erat dengan tinggi tanaman. Percobaan yang dilaporkan ini memperoleh bukti bahwa tinggi tanaman kentang berkisar antara $37-47 \mathrm{~cm}$ (data tidak ditampilkan). Peningkatan jumlah cabang diikuti dengan meningkatnya jumlah daun tanaman kentang.

Rizobakteri meningkatkan jumlah umbi per tanaman dan peningkatan terjadi antara $38 \%$ sampai $99 \%$ dibandingkan perlakuan tanpa rizobakteri. Salah satu unsur penting dalam pembentukan umbi adalah unsur Kalium. Cummings (2009) melaporkan bahwa rizobakteri indigenus dapat meningkatkan ketersediaan unsur hara seperti N, P, dan K. jika kondisi tanah membaik maka ketersediaan unsur hara yang dapat diserap akar juga akan semakin meningkat. Penambahan kapur dolomit dan pupuk kandang ayam pada percobaan ini juga ikut memperbaiki sifat biologis dan fisik tanah seperti kapasitas pegang air. Perbaikan sifat tanah tersebut tentunya memberikan dampak positif dalam meningkatkan pertumbuhan dan hasil tanaman. Munawar (2011) juga menyatakan bahwa unsur kalium berperan dalam pengangkutan hasil fotosintesis dari daun melalui floem ke jaringan organ reproduksi, sehingga memperbaiki ukuran, warna, rasa, kulit buah yang penting untuk penyimpanan dan pengangkutan.

Peningkatan hasil umbi kentang pada percobaan ini ditemukan pada semua perlakuan rizobakteri indigenus. Pertumbuhan tanaman kentang yang lebih baik diikuti oleh meningkatnya proses metabolism tanaman yang mendorong terbentuknya hasil yang lebih baik. Banyak faktor dan proses fisiologis yang terlibat dalam proses pertumbuhan dan perkembangan tanaman seperti proses perkecambahan, pertumbuhan vegetatif cepat, pembungaan, dan pematangan. Proses penyerapan hara juga dapat ditingkatkan dengan adanya asosiasi akar dengan rizobakteri (Mus et al., 2016; Glick 2012; Raza et al., 2016). Isolat L1 S4.4 merupakan isolat terbaik yang memberikan hasil rata-rata umbi per tanaman sebanyak 7,33 buah. Produksi jumlah umbi tanaman kentang diduga dipengaruhi secara langsung oleh pemberian rizobakteria indigenus, sesuai dengan perannya sebagai penyedia hara (biofertilizers).

Aplikasi pupuk kandang ayam dan setengah dosis pupuk mineral seperti urea ikut berkontribusi atas tersedianya unsur $\mathrm{N}$ pada keadaan cukup $(0,37 \%)$. Peneliti lain telah melaporkan peningkatan pertumbuhan dan ketersediaan unsur hara sebagai respon terhadap aplikasi mikroorganisme bio-efektor yang dikombinasikan dengan pupuk kandang pada tanaman jagung (Thonar et al., 2017) dan cabai paprika manis (Abbasi et al., 2015). Mpanga et al., (2018) juga melaporkan bahwa aplikasi mikroorganisme benefisial bersama pupuk kandang mampu meningkatkan akumulasi unsur $\mathrm{K}, \mathrm{Ca}$, dan $\mathrm{Mg}$ pada tajuk tanaman tomat umur 7 MST. Unsur hara tersebut berperan penting dalam proses metabolism seperti fotosintesis.

Keberadaan rizobakteri juga dapat meningkatkan serapan hara oleh akar tanaman. Unsur hara seperti $\mathrm{P}$ dapat meningkat serapannya dengan bantuan siderofor yang dihasilkan oleh rizobakteri (Dawwam et al., 2013; Vejan et al., 2016; Mpanga et al., 2018). Peningkatan ketersediaan unsur hara $P$ tersebut dangat dibutuhkan oleh tanaman hortikultura dalam pertumbuhannya (Stoffella et al., 2014). Akan tetapi, jumlah unsur $\mathrm{N}, \mathrm{P}$, dan $\mathrm{K}$ yang berlebih juga tidak baik terhadap lingkungan (Zhou et al., 2017). Penambahan bahan organik yang berfungsi sebagai ameliorant dapat meningkatkan kualitas fisik, biologis, dan kimiawi tanah melalui berbagai mekanisme. Ahmad et al. (2005) melaporkan bahwa rhibakteria mampu meningkatkan pertumbuhan tanaman karena mempunyai kemampuan melarutkan fosfat $(P)$ dan mengeluarkan berbagai macam asam organik seperti asam formiat, asetat, propionat, laktat, glikolat, fumarat, dan suksinat. Asam-asam organik ini dapat membentuk khelat organik (kompleks stabil) dengan kation $\mathrm{Al}, \mathrm{Fe}$ atau $\mathrm{Ca}$ yang mengikat $\mathrm{P}$ sehingga ion $\mathrm{H}_{2} \mathrm{PO}_{4}$ menjadi bebas dari ikatannya dan tersedia bagi tanaman untuk diserap (Sutariati, 2014). Rizobakteri juga memiliki karakter fisiologis seperti produksi enzim tertentu yang ikut berperan dalam proses biometabolisme dalam tanaman. Isolat L1 S4.4 merupakan isolat terbaik dengan produksi umbi 14,05 ton per hektar, angka ini jauh lebih tinggi dibandingkan dengan perlakuan tanpa isolat rizobakteria yang produksi per hektarnya hanya 4,70 ton.

\section{KESIMPULAN DAN SARAN}

Semua isolat rizobakteria indigenus yang diujikan ternyata mampu meningkatkan pertumbuhan dan hasil tanaman kentang var. Granola. Isolat terbaik yaitu isolat L1 S4.4 yang meningkatkan pertumbuhan dan hasil umbi tanaman kentang sampai 14,05 ton/ha. Aplikasi isolat rizobakteria indigenus juga menyebabkan terjadinya dinamika populasi gulma sebelum dan setelah perlakuan yang 
mengindikasikan terjadinya dinamika populasi gulma. Penelitian ini mendapatkan 8 species gulma dominan yaitu Bidens pilosa, Leptochloa chinensis, Eleusin indica, Agerathum conyzoides, Gynura divaricata, Richardia sp, Galinsoga parviflora, and Sonchus arvensis. Terjadi perubahan komposisi gulma pada 8 MST, gulma Eleusine indica and Gynura divaricate tidak ditemukan; sedangkan gulma Amaranthus spinosus menjadi gulma baru yang ditemukan pada pertanaman kentang $8 \mathrm{MST}$.

\section{DAFTAR PUSTAKA}

Abbasi, M.K., Musa, N., Manzoor, M. 2015. Mineralization of Soluble $P$ Fertilizers and Insoluble Rock Phosphate in Response to Phosphate-Solubilizing Bacteria and Poultry Manure and Their Effect on The Growth and P Utilization Efficiency of Chilli (Capsicum annuum L.). Biogeosciences, 12: 4607-4619.

Ahmad, M., and W.T. Frankenberger Jr. 2005. Microbial Production of Plant Growth regulators. p. 307-347. In F.B. Meeting, Jr. (Ed.). Soil Microbial Ecology. Applications in Agricultural and Environmental Management. Marcel Dekker, Inc. New York.

Andrews, S.C., Robinson, A.K. and RodríguezQuiñones, F. 2003. Bacterial Iron Homeostasis. FEMS Microbiol Rev, 27: 215-237.

Armada, E., Portela, G., Roldan, A. and Azcon, R. 2016. Combined Use of Beneficial Soil Microorganism and Agrowaste Residue to Cope with Plant Water Limitation Under Semiarid Conditions. Geoderma, 232: 640-648.

Badan Pusat Statistik. 2017. Produksi Tanaman Kentang. http://www.bps.go.id. Diakses pada tanggal 23 Agustus 2018.

Balai Pengkajian Teknologi Pertanian Sukarami. 2010. Tanaman Kentang (Solanum tuberosum L.): Komoditi Unggulan Wilayah Dataran Tinggi Kabupaten Solok. CV Hin's \& Son Printing Solok. Departemen Pertanian.

Banach, A., Kuźniar, A., Mencfel, R., and Wolińska, A. 2019. The Study on the Cultivable Microbiome of the Aquatic Fern Azolla filiculoides L. as New Source of Beneficial Microorganisms. Appl. Sci. 9: 2143

Barto, E.K., Hilker, M., Muller, F., Mohney, B.K., Weidenhamer, J.D., and Rillig, M.C. 2011. The Fungal Fast Lane: Common Mycorrhizal Networks Extend
Bioactive Zones of Allelochemicals in Soils. PLoS ONE, 6: e27195.

Beneduzi, A., Ambrosini, A. and Passaglia, L.M.P. 2012. Genetics and Molecular Biology, 35 (4) (suppl): 1044-1051.

Beneduzi, A., Ambrosini, A. and Passaglia, L.M.P. 2012. Plant growth-promoting Rhizobacteria (PGPR): Their Potential As Antagonists and Biocontrol Agents. Genetics and Molecular Biology, 35(4) (suppl): 1044-1051.

Bertholdsson N-O. 2012. Allelopathy - A Toll to Improve The Weed Comptetive Ability of Wheat to Herbicide-Resistant BlackGrass (Alopecurus myosuroides Huds). Agronomy, 2: 284-294.

Carvalho, D.D.C., Campos, V.P., Correa, R.S.B., Coimbra, J.L., Guimaraes, R.M. and Oliveira, D.F. 2007. Rhizobacteria Able to Produce Phytotoxic Metabolites. Brazilian Journal of Microbiology, 38:759-765.

Chaniago, I., Warnita, and Resti, Z. 2019. Exploration of Indigenous Rhizobacteria: in Search for their Potential as Plant Growth Promoting Bacteria at Two Potato Producing Areas in West Sumatra. IOP Conf. Ser.: Earth Environ. Sci. 347: 1-9.

Chauhan, B.S., Gill, G., Preston, C., 2006. Influence of Tillage Systems On Vertical Distribution, Seedling Recruitment And Persistence Of Rigid Ryegrass (Lolium rigidum) seed bank. Weed Science, 54: 669-676.

Compant, H. 2005. Ethylene. Chemistry of Plant Hormones. J. CRC Press Inc. Boca Raton, Florida. P. 249-264.

Cummings, S.P., 2009. The Application of Plant Growth Promoting Rhizobacteria (PGPR) in Low Input and Organic Cultivation of Graminaceous Crops; Potential and Problems. Environmental Biotechnology, 5(2):43-50.

Dalimartha, S. 2006. Atlas Tumbuhan Obat Indonesia. Jakarta : Puspa Swara.198p.

Dawwam, G.E., Elbeltagy, A., Emara, H.M., Abbas, I.H., Hassan, M.M. 2013. Beneficial Effect of Plant Growth Promoting Bacteria Isolated From The Roots of Potato Plant. Annals of Agricultural Science, 58(2): 195-201.

Egamberdiyeva, D. 2007. The effect of PGPR on Growth and Nutrient Uptake of Maize in Two Different Soils. J. Applied Soil Ecology, 36(1): 184-189.

Glick, B.R. 2012. Plant growth-promoting bacteria: Mechanisms and Applications. Scientifica, 1-15. 
Glick, B.R., Cheng, Z., Czarny, J. and Duan, J. 2007. Promotion of Plant Growth by ACC Deaminase-Producing Soil Bacteria. Eur J Plant Pathol, 119: 329339.

Hardoim, P.R., Van Overbeek, L.S., Berg, G.; Pirttilä, A.M., Compant, S.; Campisano, A.; Döring, M.; Sessitsch, A. 2015. The Hidden World within Plants: Ecological and Evolutionary Considerations for Defining Functioning of Microbial Endophytes. Microbiol. Mol. Biol. Rev, 79: 293-320.

Heyne, K. 2011. Tumbuhan Berguna Indonesia, Volume II, Yayasan Sarana Wana Jaya: Diedarkan oleh Koperasi Karyawan, Badan Litbang Kehutanan, Jakarta. 2521p.

Krewulak, K.D. and Vogel, H.J. 2008. Structural Biology of Bacterial Iron uptake. Biochim Biophys Acta, 1778:1781-1804.

Mehring, G.A.,Strenger, J.E. and HattermanValenti, H.M. 2016. Weed Control with Cover Crops in Irrigated Potatoes. Agronomy, 6(3): 1-11.

Mpanga, I.K., Dapaah, H.K., Geistlinger, J., Ludewig, U. and Neumann, G. 2018. Soil Type-Dependent Interactions of PSolubilizing Microorganisms with Organic and Inorganic Fertilizers Mediate Plant Growth Promotion in Tomato. Agronomy, 8 (10): 213- 230.

Munawar, A. 2011. Kesuburan Tanah dan Nutrisi Tanaman. IPB Press. Jakarta: Penebar Swadaya. 250p.

Mus, F., Crook, M.B., Garcia, K., Costas, A.G., Geddes, B.A., Kouri, E.D., and Paramasivan, P. 2016. Symbiotic Nitrogen Fixation and The Challenges to Its Extension to Non Legumes. Appl. Environ. Microbiol, 82(13): 3698-3710.

Nelson, D.C. and Giles, J.F. 1989. Weed Management in Two Potato (Solanum tuberosum L.) Cultivars Using Tillage and Pendimethalin. Weed Sci., 37: 229-232.

Nelson, D.C. and Thoreson, M.C. 1981. Competition Between Potatoes (Solanum tuberosum) and Weeds. Weed Sci., 29:672-677.

Osório, H., Martinez, V., Nieto, P.A., Holmes, D.S. and Quatrini, R. 2008. Microbial Iron Management Mechanisms in Extremely Acidic Environments: Comparative Genomics Evidence for Diversity and Versatility. BMC Microbiology, 8:203.

Paiman., P., Yudono, D. Indra dan B. Sunarminto. 2012. Keragaman
Komunitas Gulma pada Berbagai Kedalaman Tanah. J. Gulma, 1 (1) : 1 $-10$.

Patten, C.L. and Glick, B.R. 2002. Role of Pseudomonas Putida Indoleacetic Acid in Development of The Host Plant Root System. Appl Environ Microbiol, 68: 3795-3801.

Pérez-Fernández, M. and Alexander, V. 2017. Enhanced Plant Performance in Cicer arietinum L. Due to the Addition of a Combination of Plant GrowthPromoting Bacteria. Agriculture, 7: 4051.

Raza, W., Yousaf, S., and Rajer, F.U., 2016. Plant Growth Promoting Activity of Volatile Organic Compounds Produced by Bio-control strains. Sci. Lett., 4(1): 40-43.

Reddy S S, Stahlman P W and Geier P W, 2013, Downy brome (Bromus tectorum L.) and Broadleaf Weed Control in Winter Wheat with Acetolactate Synthase-Inhibiting Herbicides. Agronomy, 3: 340-348.

Santoyo, G., Moreno-Hagelsieb, G., OrozcoMosqueda, M.C., Glick, B.R. 2016, Plant Growth-Promoting Bacterial Endophytes. Microbiol. Res. 183: 9299.

Stoffella, P.J., He, Z.I., Wilson, S.B., OzoresHampton, M., Roe, B.E., 2014, Compost Utilization in Subtropical Horticultural Cropping Systems. pp. 95-108. In I International Symposium on Organic Matter Management and Compost in Horticulture; Biala, J., Prange, R., Raviv, M., Eds.; Acta Horticulturae: Adelaide, Australia.

Sutariati, G.A.K. 2014. Perlakuan Benih dengan Agen Biokontrol untuk Pengendalian Penyakit Antraknosa, Peningkatan Hasil dan Mutu Benih Cabai. [Disertasi]. Sekolah Pascasarjana IPB. Bogor.

Suveltri, B., Z. Syam, dan Solfiyeni. 2014. Analisa Vegetasi Gulma Pada Pertanaman Jagung (Zea mays L) Pada Lahan Olah Tanah Maksimal di Kabupaten Lima Puluh Kota. Jurnal Biologi Universitas Andalas, 3(2): 103108

Thonar, C., Lekfeldt, J.D.S., Cozzolino, V., Kundel, D., Kulhánek, M., Mosimann, C., Neumann, G., Piccolo, A., Rex, M., Symanczik, S. 2017. Potential of Three Microbial Bio-Effectors to Promote Maize Growth and Nutrient Acquisition From Alternative Phosphorous Fertilizers in Contrasting Soils. Chem. 
Jurnal Agroteknologi, Vol. 11 No. 1, Agustus $2020: 1$ - 10

Biol. Technol. Agric. 4 (7): 1-16

Vejan, P., Abdullah, R., Khadiran, T., Ismail, S. and Boyce, A. M. 2016. Role of Plant Growth Promoting Rhizobacteria in Agricultural Sustainability-A Review. Molecules, 21 (573): 1-17.

Zhou, X., Qiao, M., Wang, F.H., Zhu, Y.G., 2017, Use of Commercial Organic Fertilizer Increases The Abundance Ofantibiotic Resistance Genes and Antibiotics in Soil. Environ. Sci. Pollut. Res., 24: 701-710. 
Pengaruh Introduksi Isolat Rizobakteri Indigen Terhadap Tanaman Kentang (Qolby, et al.) 